EXTENDED REPORT

\title{
Anti-CD4 monoclonal antibody treatment in acute and early chronic antigen induced arthritis: influence on macrophage activation
}

\author{
K Nissler, D Pohlers, M Hückel, J Simon, R Bräuer, R W Kinne
}

Ann Rheum Dis 2004;63:1470-1477. doi: 10.1136/ard.2003.013060

See end of article for authors' affiliations

Correspondence to:

Professor R W Kinne,

Experimental

Rheumatology Unit,

Friedrich Schiller

University, D-07740 Jena,

Germany;

Raimund.W.Kinne@

rz.uni-jena.de

Accepted 9 January 2004

\begin{abstract}
Objective: To investigate the indirect effects of anti-CD4 treatment on the functions of macrophages (CD4 in mice) in the acute and early chronic phase of mouse antigen induced arthritis (AIA).

Methods: C57BL/6 mice with AIA were treated intraperitoneally with the anti-CD4 mAb GK1.5 or control rat lgG on days $-1,0,1,3,5$, and 7 . Proinflammatory cytokines (IL $1 \beta, \mathrm{IL} 6$, and TNF $\alpha$ ) were quantified by sandwich ELISA in joint extracts, serum, and supernatants of ex vivo stimulated spleen/lymph node cells or peritoneal macrophages (+LPS/IFN $\gamma$ ). Nitric oxide (NO) levels in supernatants of ex vivo stimulated peritoneal macrophages were measured by the Griess reaction. Proteolytic activity in joint homogenates was analysed by gelatin, casein, and elastin zymography, and substrate assays.

Results: Anti-CD4 treatment significantly reduced joint swelling in acute (days 3,5) and early chronic AIA (day 7) and diminished inflammation and destruction scores in late chronic AIA (day 21). On day 3, antiCD4 treatment significantly reduced IL6 levels in all compartments. IL1 $\beta$ was reduced in joint extracts, unaffected in serum or cells from lymphoid organs, and increased in stimulated peritoneal macrophages. TNF $\alpha$ was significantly increased in the joints, decreased in serum, and otherwise unchanged. NO production by stimulated peritoneal macrophages was significantly reduced by anti-CD4 treatment. Lower activity of matrix metalloproteinases and neutrophil elastase was seen in joint extracts of anti-CD4 treated animals than in $\lg G$ treated AIA controls.

Conclusion: $\mathrm{CD} 4^{+} \mathrm{T}$ cell directed treatment had strong local and systemic effects on macrophages. These indirect effects may contribute to the reduction of destructive mediators/joint destruction in AIA.
\end{abstract}

$\mathrm{R}$ heumatoid arthritis (RA) in humans is a systemic disorder of unknown aetiology, characterised by chronic inflammation and progressive destruction of arthritic joints, as well as synovial infiltration of $\mathrm{T}$ helper (Th) cells, polymorphonuclear neutrophilic leucocytes (PMNs), and macrophages (reviewed by Fox, ${ }^{1}$ Kinne et al, ${ }^{2}$ Pillinger and Abramson $^{3}$ ). The abundance of $\mathrm{CD}^{+}$Th cells in the RA synovial membrane and the association between RA and certain HLA-DR or HLA-DQ alleles ${ }^{4}$ have provided the rationale for therapeutic application of anti-CD4 monoclonal antibodies (mAbs; reviewed by Schulze-Koops and Lipsky ${ }^{5}$ ). Despite disappointing results of anti-CD4 treatment in controlled clinical trials, beneficial effects of newer, non-depleting anti-CD4 mAbs ${ }^{6}$ may lead to a revival of this principle.

Anti-CD4 mAbs have shown clinical efficacy in several experimental arthritis models; however, differential effects in certain models and/or stages of disease depend on the depleting or non-depleting character of the mAbs, ${ }^{7}$ as well as on the CD4 epitope recognised by the particular mAb. ${ }^{8}$ Antigen induced arthritis (AIA) is induced by systemic immunisation with antigen (methylated bovine serum albumin (mBSA)), followed by local elicitation through intra-articular injection of mBSA. ${ }^{9} \mathrm{CD} 4^{+} \mathrm{T}$ cells have a central role in experimental arthritis, as shown by successful treatment with mAbs against the $\mathrm{T}$ cell receptor, ${ }^{10}$ with $\mathrm{T}$ cell directed drugs like ciclosporin $\mathrm{A},{ }^{11}$ or by $\mathrm{T}$ cell transfer of AIA to severe combined immunodeficient (SCID) mice. ${ }^{12}$ However, cells of the monocytic lineage are also crucially involved in the pathogenesis of $\mathrm{AIA}^{13}$ and RA (reviewed by Kinne et $a l^{2}$ ). Macrophages appear to have a pivotal role in arthritis because they are numerous in the inflamed synovial membrane and at the cartilage-pannus junction. They show clear signs of activation, such as overexpression of major histocompatibility complex class II molecules, proinflammatory or regulatory cytokine growth factors, and matrix metalloproteinases (MMPs). ${ }^{14}$ Therefore, macrophages possess broad proinflammatory and destructive abilities, and they contribute considerably to inflammation and joint destruction in acute and chronic phases of arthritides.

Fully activated $\mathrm{T}$ cells provide numerous stimulatory signals to monocytes/macrophages-for example, the cytokines interferon $\gamma$ (IFN $\gamma$ ) and granulocyte monocyte-colony stimulating factor, inducing their differentiation or activation, or both. Consequently, anti-CD4 treatment may affect not only $\mathrm{T}$ cells but also macrophages, whether indirectly (as in mice, which carry $\mathrm{CD}^{-}$macrophages) or directly and indirectly (as in humans, who carry $\mathrm{CD}^{+}$macrophages). ${ }^{15}$ Therefore, local and systemic secretion of the proinflammatory macrophage products interleukin (IL) $1 \beta$, IL6, tumour necrosis factor $\alpha(\mathrm{TNF} \alpha)$, and nitric oxide (NO), as well as the local production of tissue degrading enzymes, were investigated during anti-CD4 treatment of acute and early chronic AIA (day -1 to day 7 ).

\section{METHODS}

\section{Animals and antibodies}

Female C57BL/6 mice (8-10 weeks of age) were obtained from the Animal Research Facility, Friedrich Schiller

\footnotetext{
Abbreviations: AIA, antigen induced arthritis; ELISA, enzyme linked immunosorbent assay; IFN $\gamma$, interferon $\gamma$; IL, interleukin; LPS, lipopolysaccharide; mAb, monoclonal antibody; mBSA, methylated bovine serum albumin; MMP, matrix metalloproteinase; NE, neutrophil elastase; NO, nitric oxide; PBS, phosphate buffered saline; PMN, polymorphonuclear leucocyte; RA, rheumatoid arthritis; SDS-PAGE, sodium dodecyl sulphate-polyacrylamide gel electrophoresis; TNF $\alpha$, tumour necrosis factor $\alpha$
} 
University, Jena. They were kept under standard conditions, 10 in each cage with food/water freely and a 12 hours light/ 12 hours dark cycle. All animal studies were approved by the governmental commission for animal protection. The rat-antimouse CD4 mAb GK1.5 (IgG2b) was purified from hybridoma (GK1.5; ATCC TIB-207; Manassas, VA, USA) culture supernatant, the rat IgG from Lewis rat serum (containing 58\% IgG2b, 25\% IgG2a, 13\% IgGl, and $4 \%$ $\left.\operatorname{IgG} 2 \mathrm{c}^{16}\right)$, both by affinity chromatography on HiTrap Protein-G columns (Amersham-Pharmacia, Freiburg, Germany).

\section{AIA and anti-CD4 treatment}

The animals were immunised on days -21 and -14 by subcutaneous injection of $100 \mu \mathrm{g}$ mBSA in $50 \mu \mathrm{l}$ saline, emulsified in $50 \mu \mathrm{l}$ complete Freund's adjuvant (Sigma, Deisenhofen, Germany), which was adjusted to $2 \mathrm{mg} / \mathrm{ml}$ with heat-killed Mycobacterium tuberculosis (strain H37RA; Difco, Detroit, MI, USA). In addition, the mice received an intraperitoneal injection of $2 \times 10^{9}$ heat inactivated Bordetella pertussis (Pertussis Reference Centre, Krankenhaus Friedrichshain, Berlin, Germany). Arthritis was elicited on day 0 by injection of $100 \mu \mathrm{g}$ mBSA in $25 \mu \mathrm{l}$ saline into the right knee joint cavity, while the left knee joint remained untreated. For anti-CD4 treatment, the mice $(n=10)$ received $200 \mu \mathrm{g}$ of the antimouse CD4 mAb GKl.5 on days $-1,0,1,3,5$, and 7 of AIA intraperitoneally. Note that the terms "therapy", "treatment", and "clinical effects" are used in this study for the sake of presentation, although AIA clearly represents an experimentally induced disorder. The control group $(\mathrm{n}=10)$ was treated with $200 \mu \mathrm{g}$ rat IgG instead. Joint swelling was measured on days $0,1,3,5$, 7, 14, and 21 with an Oditest vernier caliper (Kroeplin Längenmesstechnik, Schlüchtern, Germany) and expressed as the difference (in $\mathrm{mm}$ ) between the diameter of the right and the left knee joint.

The experimental data are derived from three independent treatment studies, which showed no significant difference for the joint swelling of the two treatment groups.

\section{Histology}

Both knee joints were removed on day 3 (acute phase) or on day 21 of AIA (late chronic phase), skinned, and fixed in phosphate buffered formalin. Paraffin sections $(5 \mu \mathrm{m})$ of EDTA decalcified joints were stained with haematoxylin and eosin. The severity of arthritis was examined by grading the cellular infiltration and joint destruction, as previously described..$^{13}$

\section{Preparation of joint extracts}

Whole knee joints were removed on day 3, snap frozen in liquid $\mathrm{N}_{2}$, and stored at $-70^{\circ} \mathrm{C}$. The extracts were obtained by grinding the frozen joints under liquid $\mathrm{N}_{2}$ with a mortar and a pestle, followed by addition of $2 \mathrm{ml}$ saline and homogenisation with a Dounce homogeniser. After centrifugation for 20 minutes at $1500 \mathrm{~g}$, the supernatant was split into aliquots and frozen at $-70^{\circ} \mathrm{C}$ until further use. Protein concentrations were determined by the BCA assay (Pierce, Rockville, IL, USA) and the measured cytokine levels (in pg) were then normalised to the concentration of total protein (in $\mathrm{mg})$.

\section{Isolation and stimulation of cells}

Peritoneal cells were harvested on day 3 by peritoneal lavage with $7 \mathrm{ml}$ ice cold phosphate buffered saline (PBS) containing $5 \mathrm{IU} / \mathrm{ml}$ sodium heparin (Liquemin N 25.000; Hoffman-La Roche, Grenzach-Wyhlen, Germany). Cells were washed and resuspended in RPMI 1640, 10\% fetal calf serum, $2 \mathrm{mM}$ L-glutamine, $10 \mathrm{mM}$ Hepes (all from Gibco, Karlsruhe, Germany), 100 U/ml penicillin (Jenapharm, Jena,
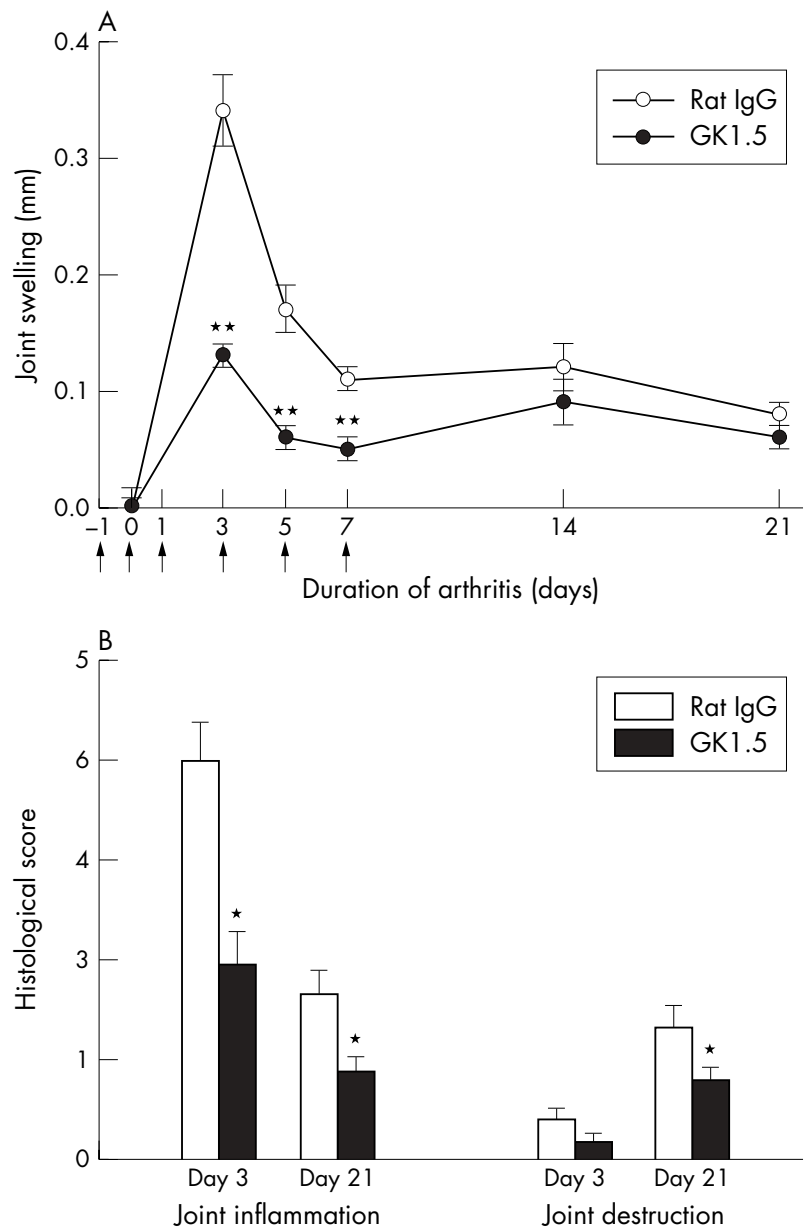

Figure 1 Joint swelling and histology of AIA. (A) Time course of joint swelling in AIA after treatment with the anti-CD4 mAb GK1.5 or control rat lgG. Results are expressed as means (SEM) of 10 individual animals in each group. Arrows indicate the days of treatment (days $-1,0,1,3$, 5, and 7). (B) Histological score of joint inflammation and joint destruction in the acute phase (day 3) and the chronic phase (day 21) of AIA. Results are expressed as means (SEM) of 10 individual animals in each group. ${ }^{*} p \leqslant 0.05,{ }^{* *} p \leqslant 0.01$ in comparison with lgG treated controls.

Germany), $100 \mu \mathrm{g} / \mathrm{ml}$ streptomycin (Grünenthal, Stolberg, Germany)-thereafter called $\mathrm{RlOF}^{+}$. Cells were seeded at $1 \times 10^{6}$ cells per well in 24 well plates and allowed to adhere for 2 hours at $37^{\circ} \mathrm{C}$ in a humidified $5 \% \mathrm{CO}_{2}$ atmosphere. After attachment, non-adherent cells were removed by extensive washing with warm RPMI 1640 medium and re-counted to calculate by subtraction the number of adherent cells in the well. The remaining adherent cells normally consist of $>95 \%$ macrophages. ${ }^{17}$ For analysis of cytokine and NO production, adherent macrophages were stimulated for 24 hours with lipopolysaccharide (LPS $1 \mu \mathrm{g} / \mathrm{ml} ; \quad E$ coli serotype O26:B6; Sigma, Deisenhofen, Germany) and recombinant murine IFN $\gamma$ ( $1 \mathrm{ng} / \mathrm{ml}$, R\&D Systems, Wiesbaden, Germany).

Single cell suspensions were prepared from lymph nodes and spleens in $\mathrm{R} 10 \mathrm{~F}^{+}$, seeded at $1 \times 10^{6}$ cells per well in 24 well plates, and stimulated with LPS/IFN $\gamma$ as above. Endotoxin contamination of all media and solutions was $<1 \mathrm{ng} / \mathrm{ml}$ (Limulus Amoebocyte Lysate test; E-Toxate, Sigma). In all cases, cell-free supernatants were harvested after 24 hours, split into aliquots, and stored at $-70^{\circ} \mathrm{C}$ until cytokine analysis. 

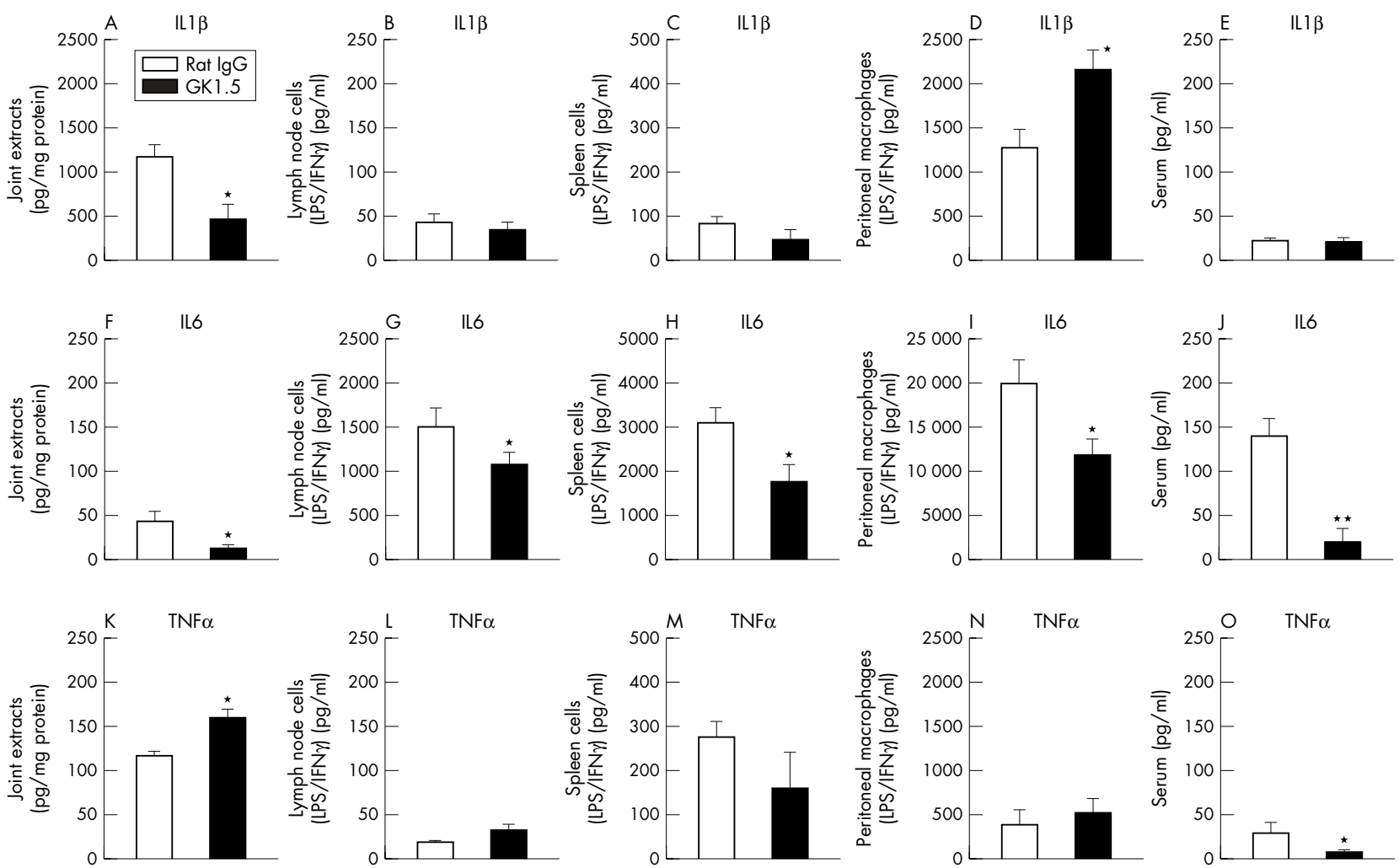

Figure 2 Cytokine levels on day 3 of AIA. Concentrations of ILI $\beta(A, B, C, D, E), I L 6(F, G, H, I, J)$, and TNF $\alpha(K, L, M, N, O)$ in joint extracts, supernatants of stimulated lymph node cells, spleen cells, or peritoneal macrophages, as well as serum of GK1.5 treated or rat lgG treated mice, as determined by sandwich ELISA. Results are expressed as means (SEM) ( $n=6$ for each group). ${ }^{*} p \leqslant 0.05,{ }^{* *} p \leqslant 0.01$ in comparison with lgG treated controls.

\section{Cytokine analysis}

Concentrations of IL1 $\beta$, IL6, and TNF $\alpha$ were determined by sandwich enzyme linked immunosorbent assay (ELISA) according to standard procedures using the following antibody pairs: MAB401 and BAF401 (IL1 $\beta$; R\&D Systems); MP5-20F3 and MP5-32C11 (IL6; BD Pharmingen, Heidelberg, Germany); G281-2626 and MP6-XT3 (TNFa; BD Pharmingen).

\section{Determination of NO production}

NO production was determined by the Griess reaction, as described previously. ${ }^{18}$

\section{Immunohistochemistry}

Knee joints were removed completely on day 3 of AIA and snap frozen in isopropane $/ \mathrm{N}_{2}$. Cryosections of $6 \mu \mathrm{m}$ were prepared and air dried. The slides were incubated for 1 hour with primary mAb against the Ly-6G molecule on PMNs (RB6-8C5; BD Pharmingen) or isotype control rat IgG2b $\mathrm{mAb}$. After rinsing, the slides were incubated for 1 hour with secondary goat-antirat IgG conjugated with peroxidase (Dianova, Hamburg, Germany); diaminobenzidine was used as a substrate. The slides were washed and counterstained with haematoxylin. Positively stained cells were scored semiquantitatively by two "blinded" observers $(0=$ no; $1=$ weak; 2 = medium; $3=$ strong infiltration of PMNs).
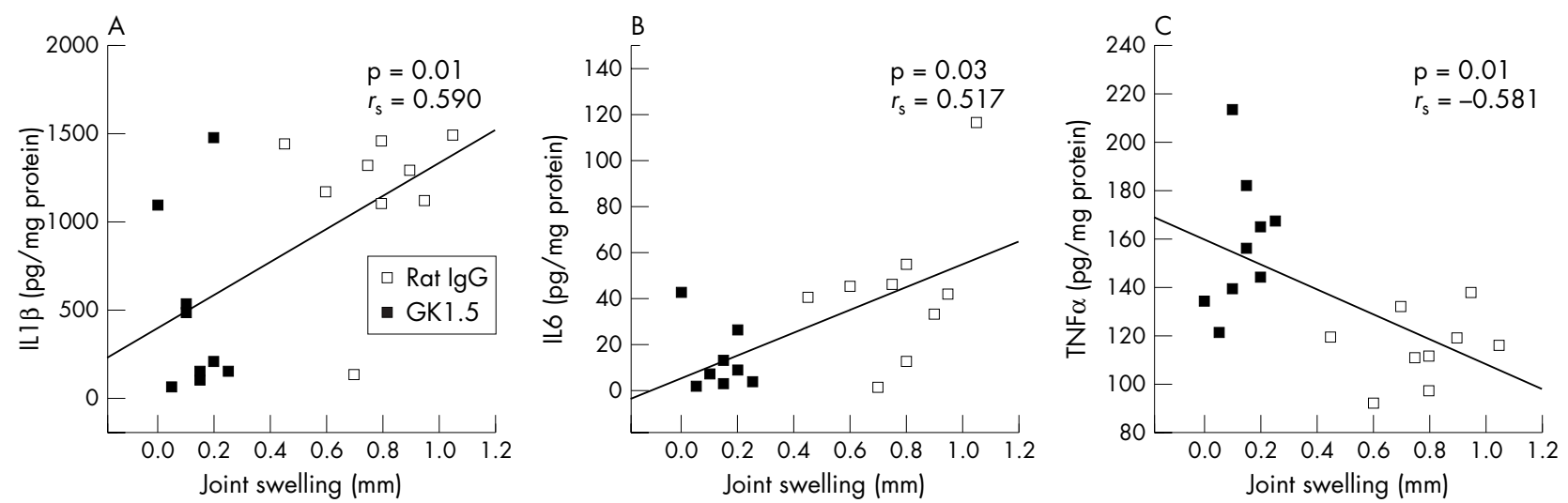

Figure 3 Correlations between cytokine levels in joint extracts and joint swelling on day 3 of AIA. Correlations (Spearman rank test) between joint ILI $\beta$, IL6, and TNF $\alpha$ levels and joint swelling of individual mice treated with GK1.5 or rat lgG (total of $n=18$ for each cytokine). 


\section{Determination of proteolytic activity}

Joint extracts were first diluted with PBS to a protein content of $1 \mathrm{mg} / \mathrm{ml}$ (BCA assay). For zymography, $50 \mu \mathrm{l}$ of joint extracts from GK1.5 treated $(n=6)$ or rat IgG treated animals $(n=5)$ were separated by electrophoresis on a sodium dodecyl sulphate-polyacrylamide gel (SDS-PAGE) supplemented with gelatin $(0.6 \mathrm{mg} / \mathrm{ml})$, casein $(0.5 \mathrm{mg} / \mathrm{ml})$, or elastin $(2 \mathrm{mg} / \mathrm{ml})$. After SDS-PAGE, the gels were washed twice with $2.5 \%$ Triton X-100 for 30 minutes to remove SDS, once with aqua dest., and finally equilibrated with incubation buffer $\left(100 \mathrm{mM}\right.$ Tris/ $\mathrm{HCl}, 30 \mathrm{mM} \quad \mathrm{CaCl}_{2}, 0.01 \% \mathrm{NaN}_{3}$, $\mathrm{pH}$ 7.6). The gel was then incubated at $37^{\circ} \mathrm{C}$ for 20 hours (gelatin, casein) or 72 hours (elastin). For inhibition studies, the incubation buffer was supplemented with MeOSuc-AlaAla-Pro-Val-CMK (200 $\mu$ M; Bachem, Heidelberg, Germany), a specific inhibitor of neutrophil elastase. Staining of protein was performed with Coomassie blue solution $(10 \mathrm{ml}$ acetic acid, $40 \mathrm{ml}$ aqua dest., $50 \mathrm{ml}$ methanol, 0.25\% Coomassie blue G250) for 40 minutes, de-staining was carried out in methanol/acetic acid/aqua dest. (25/7/68; vol/vol/vol).

For determination of "total" MMP activity, $2 \mu \mathrm{l}$ of joint extracts were incubated with $5 \mu \mathrm{M}$ MCA-Pro-Leu-Gly-Leu$\mathrm{DAP}(\mathrm{DNP})$-Ala-Arg- $\mathrm{NH}_{2}$ (Bachem) in $100 \mu \mathrm{l}$ incubation buffer ( $100 \mathrm{mM}$ Tris/HCl, $30 \mathrm{mM} \mathrm{CaCl}_{2}, 0.05 \%$ Brij, pH 7.6) for 3 hours at $37^{\circ} \mathrm{C}$. Different active MMPs cleave the quenched substrate with varying specific activities, ${ }^{19}$ therefore increasing the fluorescence. This was measured in 96 well FLUOTRAC plates (Greiner) using a FLUOstar Galaxy (BMG, Offenburg, Germany; excitation $330 \mathrm{~nm}$, emission $390 \mathrm{~nm}$ ). The combined activity of active and pro-MMP was determined after activation of pro-MMP with $2 \mathrm{mM}$ aminophenyl mercuric acetate for 15 minutes before substrate addition. For elastase chromogenic assays, $50 \mu \mathrm{l}$ of joint extracts were incubated in a 96 well plate with $50 \mu \mathrm{l}$ of $1 \mathrm{mM}$ MeOSuc-Ala-Ala-Pro-Val-pNA (Bachem) in incubation buffer ( $100 \mathrm{mM}$ Tris/HCl, $0.5 \mathrm{M} \mathrm{NaCl}, 2 \mathrm{mM} \mathrm{CaCl}_{2}, 0.01 \%$ Brij, $\mathrm{pH} 8.2$ ) for 2 hours at $37^{\circ} \mathrm{C}$. Subsequently, the absorbance was measured in a microplate reader (SLT, Crailsheim, Germany) at $405 \mathrm{~nm}$ (reference $690 \mathrm{~nm}$ ).

\section{Statistics}

The non-parametric Mann-Whitney U test (two tailed) was applied for analysis of the experimental variables, with significant differences between the anti-CD4 mAb and control IgG group accepted for $\mathrm{p} \leqslant 0.05$. The Spearman rank

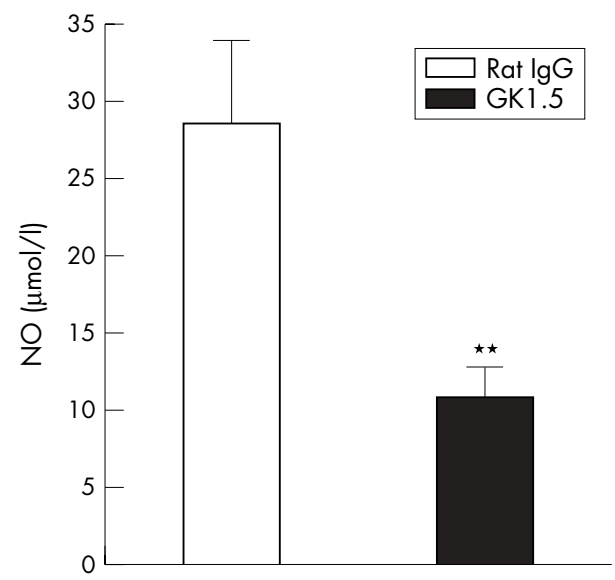

Figure 4 NO levels on day 3 of AIA. Levels of NO in culture supernatants of LPS/IFN $\gamma$ stimulated peritoneal macrophages from GK1.5 treated or rat $\lg G$ treated mice. Results are expressed as means (SEM) ( $n=6$ for each group). ${ }^{* *} p \leqslant 0.01$ in comparison with lg $G$ treated controls.

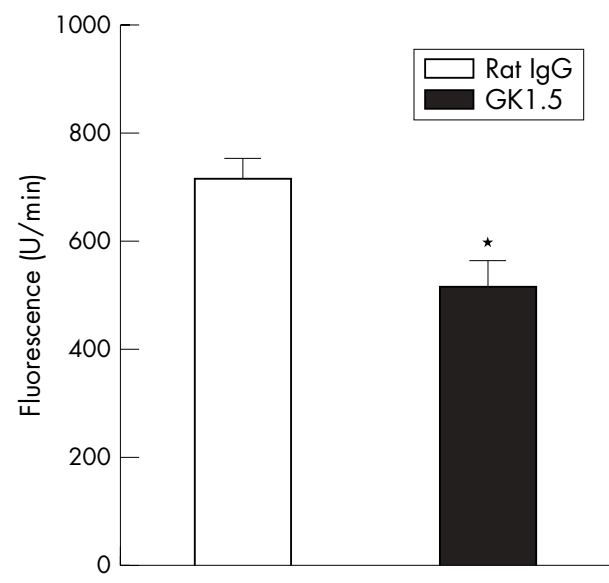

Figure 5 "Total" MMP activity in joint extracts on day 3 of AIA. Total activity of MMP was determined by cleavage of the peptide MCA-ProLeu-Gly-Leu-DAP (DNP-Ala-Arg-NH $\mathrm{NH}_{2}$ ), resulting in an increase of fluorescence. Results are expressed as means (SEM) ( $n=8$ for each group). ${ }^{*} \mathrm{p} \leqslant 0.05$ in comparison with lgG treated controls.

correlation test $\left(r_{\mathrm{s}}\right)$ was used to analyse correlations among experimental variables and between these variables and the clinical status of individual mice $(p \leqslant 0.05)$. Analyses were performed using the SPSS 10.0 program (SPSS Inc; Chicago, IL, USA).

\section{RESULTS}

\section{Clinical effects}

Treatment with the depleting anti-CD4 mAb GK1.5 on days $-1,0,1,3,5$, and 7 significantly decreased joint swelling already in the acute phase (days 3, 5) and in the early chronic phase of AIA (day 7) compared with rat IgG treated controls (fig lA).

Decreased disease activity after GK1.5 treatment was confirmed by examination of joint histology. The signs of joint inflammation (as defined by hyperplasia of the synovial lining layer and cellular infiltration) were significantly reduced in GK1.5 treated animals both in acute (day 3) and late chronic AIA (day 21; fig 1B). The joint destruction score, defined as pannus formation and erosion of cartilage and bone, became significantly reduced in late chronic AIA (fig 1B), the phase with maximal joint destruction in untreated AIA. ${ }^{13}$

\section{Cytokine levels in local and systemic compartments}

Because of the known role of locally and systemically activated macrophages in the AIA model, the levels of major monocyte/macrophage cytokines were evaluated in joint extracts, supernatants of LPS/IFN $\gamma$ stimulated lymph node cells, spleen cells, and peritoneal macrophages, as well as the serum.

\section{ILI $\beta$}

In the joints, anti-CD4 treatment significantly decreased ILI $\beta$ (fig 2A). Whereas anti-CD4 treatment had no effects on stimulated lymph node or spleen cells and in the serum (fig 2B, C, E), a significant increase of ILl $\beta$ was detected in cultures of LPS/IFN $\gamma$ stimulated peritoneal macrophages from GK1.5 treated animals (fig 2D). Interestingly, this effect was significantly and negatively correlated with the joint swelling $\left(\mathrm{p}=0.04 ; r_{\mathrm{s}}=-0.636, \mathrm{n}=12\right)$.

\section{IL6}

Anti-CD4 treatment significantly reduced levels of IL6 in all compartments investigated-that is, joint extracts, LPS/IFN $\gamma$ 
A Gelatin

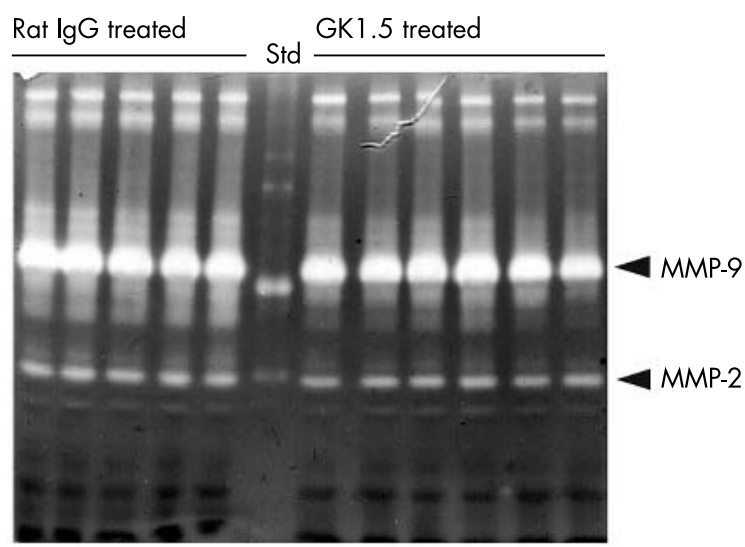

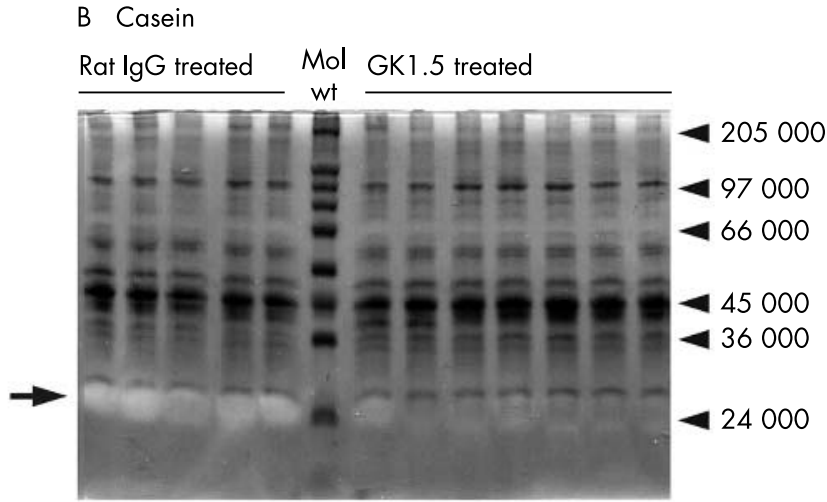

24000

\section{Elastin}
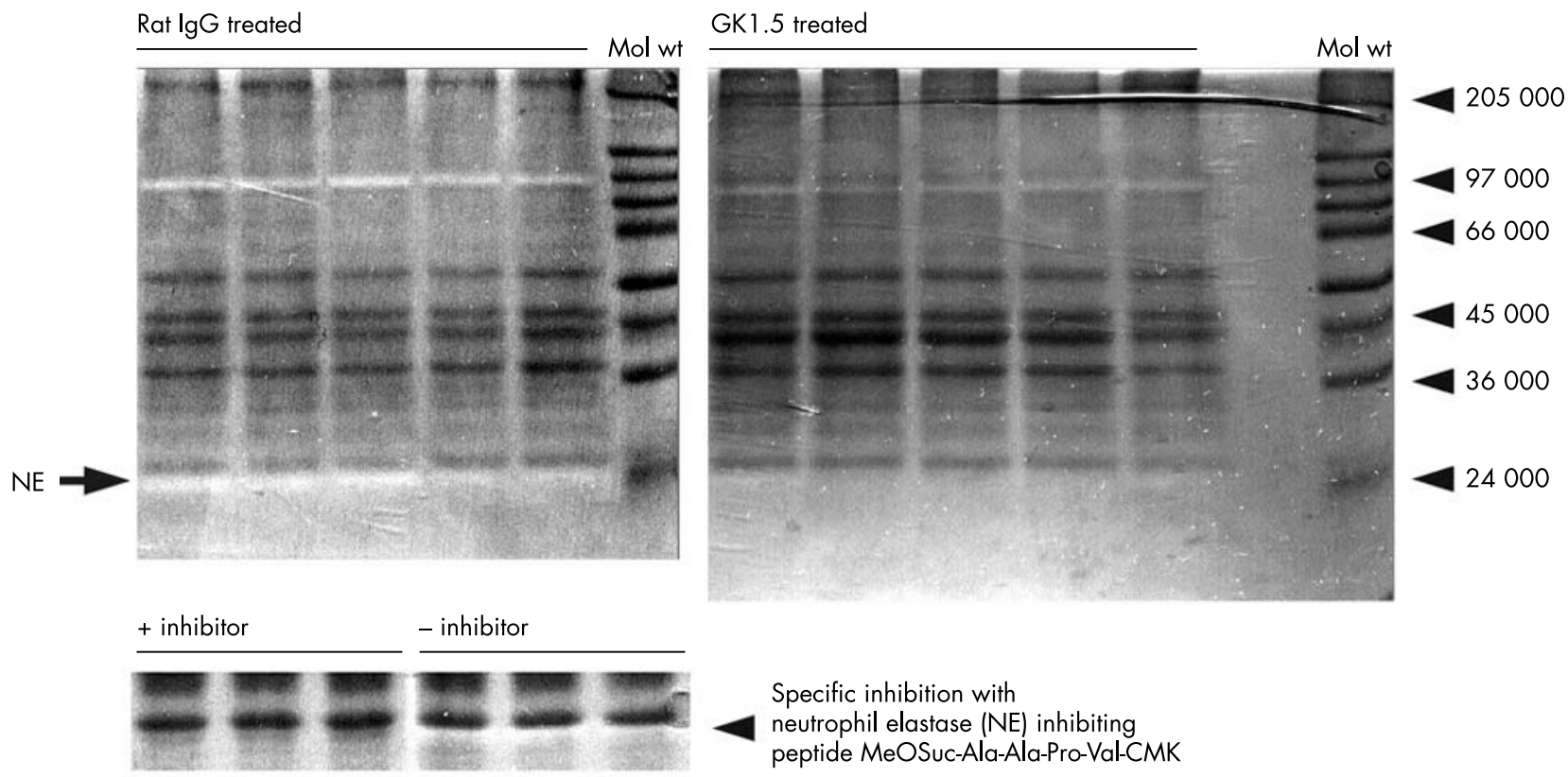

Specific inhibition with

neutrophil elastase (NE) inhibiting

peptide MeOSuc-Ala-Ala-Pro-Val-CMK

Figure 6 Zymography of joint extracts on day 3 of AIA. Zymography of equal amounts (protein content) of joint extracts from GK1.5 treated or rat IgG treated mice using (A) gelatin, (B) casein, or (C) elastin as a substrate. Markers of molecular weight (Mol wt) or the positions of recombinant human MMP standards (Std) are indicated on the right. Elastase activity in (C) was blocked by the specific inhibitor MeOSuc-Ala-Ala-Pro-Val-CMK.

stimulated lymph node cells, spleen cells, or peritoneal macrophages, and in the serum (fig $2 \mathrm{~F}-\mathrm{J}$ ). In the case of peritoneal macrophages, the effect of anti-CD4 treatment was confirmed at a lower concentration level (IgG treated: $100 \mathrm{pg} / \mathrm{ml}$; anti-CD4 treated: $25 \mathrm{pg} / \mathrm{ml} ; \mathrm{p} \leqslant 0.01$ ) also in non-stimulated cells.

\section{$\mathrm{TNF} \alpha$}

Treatment with GK1.5 mAbs induced a moderate but significant increase of the TNF $\alpha$ concentration in joint extracts (fig $2 \mathrm{~K}$ ). In contrast, there was a profound and significant decrease of TNF $\alpha$ levels in the serum (fig 2O), whereas LPS/IFN $\gamma$ stimulated lymph node cells, spleen cells, or peritoneal macrophages were not significantly affected (figs $2 \mathrm{~L}-\mathrm{N}$ ).

Significant, positive correlations were detected between the degree of joint swelling in IgG treated or anti-CD4 treated mice and the joint levels of $\operatorname{ILl} \beta\left(\mathrm{p}=0.01 ; r_{\mathrm{s}}=0.590 ; \mathrm{n}=18\right)$ and IL6 ( $\left.\mathrm{p}=0.03 ; r_{\mathrm{s}}=0.517 ; \mathrm{n}=18\right)$ (figs $3 \mathrm{~A}$ and $\left.\mathrm{B}\right)$, indicating a contribution of these cytokines to joint inflammation. In contrast, a significant negative correlation was seen between joint swelling and the joint levels of TNF $\alpha$ $\left(\mathrm{p}=0.01 ; r_{\mathrm{s}}=-0.581 ; \mathrm{n}=18\right.$; fig $\left.3 \mathrm{C}\right)$. Also, positive correlations were found between the IL6 concentrations in all systemic compartments (except for the spleen) and the severity of joint swelling (lymph nodes: $\mathrm{p}=0.02 ; r_{\mathrm{s}}=0.643$; $\mathrm{n}=12 ;$ peritoneum: $\mathrm{p}=0.02 ; r_{\mathrm{s}}=0.643 ; \mathrm{n}=12 ;$ serum: $\left.\mathrm{p}=0.003 ; r_{\mathrm{s}}=0.629 ; \mathrm{n}=20\right)$.

\section{NO levels in peritoneal macrophages}

NO levels in supernatants of LPS/IFN $\gamma$ stimulated peritoneal macrophages from GK1.5 treated animals were significantly reduced in comparison with those from IgG treated mice (fig 4). 


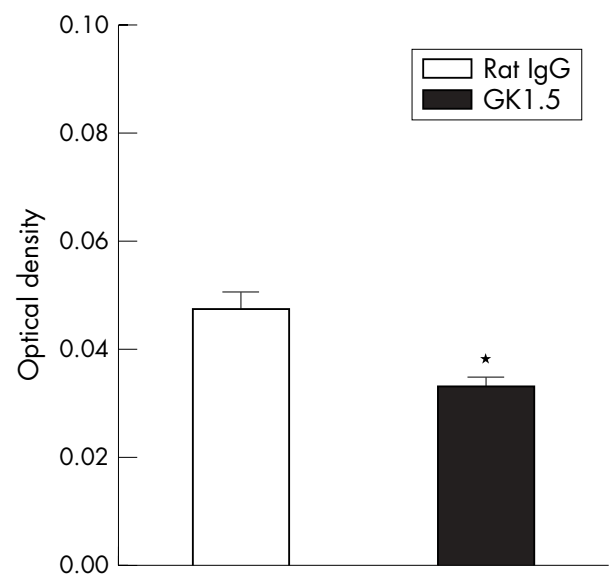

Figure 7 Elastase activity in joint extracts on day 3 of AIA. Activity of neutrophil elastase was determined by cleavage of the elastase-specific, synthetic substrate MeOSuc-Ala-Ala-Pro-Val-pNA, resulting in an increase of absorbance. Results are expressed as means (SEM) ( $n=8$ for each group). ${ }^{*} p \leqslant 0.05$ in comparison with lgG treated controls.

\section{Proteolytic activity in joint extracts}

MMP and other proteinases are major effector molecules in the destructive process in arthritis. In view of numerically or significantly reduced destruction scores in acute and late chronic AIA after anti-CD4 treatment (fig 1B), the proteolytic activity was investigated in joint extracts derived from acute AIA (day 3). Treatment with GK1.5 significantly reduced the total MMP activity, as measured by cleavage of an MMPspecific, fluorogenic peptide (fig 5). This could not be assigned to changes in MMP-2 or MMP-9 activity, because zymography showed no differences in gelatinolytic activity between anti-CD4 treatment and IgG controls, especially for MMP-2 and MMP-9 (fig 6A). The caseinolytic activity seen at a molecular weight of about $28 \mathrm{kDa}$ was also strongly decreased in GK1.5 treated mice (fig 6B). A comparable difference was noted in the same molecular weight range using elastin as a substrate. By addition of the specific inhibitor MeOSuc-Ala-Ala-Pro-Val-CMK during the incubation, the elastinolytic activity at $28 \mathrm{kDa}$ was unequivocally identified as neutrophil elastase (NE) (fig 6C). The significantly reduced proteolytic activity of $\mathrm{NE}$ in joint extracts from GK1.5 treated mice was also confirmed using a chromogenic assay with an NE-specific synthetic substrate (fig 7).

\section{Determination of PMN infiltration}

Immunohistological staining of the arthritic joints on day 3 showed that anti-CD4 treatment did not significantly decrease the degree of PMN infiltration (2.6 (0.2) rat IgG; 2.3 (0.3) GK1.5; mean (SEM)), excluding PMN depletion as a reason for the decreased NE activity in joint extracts.

\section{DISCUSSION}

\section{Anti-CD4 treatment suppresses joint inflammation} and destruction

Treatment with the depleting anti-CD4 mAb GK1.5 during acute and early chronic AIA (days -1 to 7 ) significantly suppressed joint swelling and histological signs of inflammation in the acute phase of AIA (day 3) and significantly reduced both joint inflammation and destruction in late chronic AIA (day 21). To our knowledge, this is the first evidence that monotherapy with anti-CD4 mAbs not only ameliorates clinical and histological signs of joint inflammation but also prevents/reduces joint destruction in AIA. By comparison, anti-destructive effects have only been seen after treatment of arthritis models either with broadly reactive anti- $\alpha \beta$-T cell receptor antibodies ${ }^{10}{ }^{20}$ or with combinations of anti-CD4 mAbs and anti-macrophage reagents - that is, anti$\mathrm{TNF} \alpha \mathrm{mAbs}^{21}$ or liposomes containing clodronate. ${ }^{22}$

\section{Anti-CD4 treatment reduces IL6 both locally and systemically}

Anti-CD4 treatment significantly reduced the levels of IL6 in every compartment investigated-that is, joints, lymphoid organs, peritoneum, and serum. IL6 seems to play a clearly proinflammatory part in AIA, as shown by a significant correlation of IL6 levels in synovial fluid and serum with the severity of disease, ${ }^{11}$ and by the peak levels of this cytokine in joints, peritoneum, and serum in the acute phase. ${ }^{13}$ Our study also showed positive correlations between the severity of joint swelling and the IL6 concentrations in all compartments (except for the spleen; fig 3). Although both pro- and antiinflammatory properties have been assigned to IL6, ${ }^{23-25}$ this study seems to support a prevalent proinflammatory role of this cytokine. Thus, local and systemic reduction of IL6 by anti-CD4 treatment may contribute to the amelioration of disease activity in AIA, as also reported in human $\mathrm{RA}^{15}$ and SLE. ${ }^{26}$

\section{Diverging effects of anti-CD4 treatment on local and systemic levels of IL $1 \beta$}

Anti-CD4 treatment significantly reduced local IL1 $\beta$ levels in acute AIA (day 3; fig 2A). This may contribute to the reduced destruction scores at this stage (fig $1 \mathrm{~B}$ ), as supported by a significant, positive correlation between local ILı $\beta$ levels and joint swelling (fig 3).

In contrast with the high levels of ILl $\beta$ in the joint (about $1170 \mathrm{pg} / \mathrm{ml}$ ), this cytokine was found at relatively low systemic levels in the spleen, lymph nodes, serum, and non-stimulated peritoneal macrophages $(25-100 \mathrm{pg} / \mathrm{ml})$ in acute AIA, in line with previously published data. ${ }^{13}$ This low constitutive expression in untreated AIA and the lack of changes in any systemic compartment (except for peritoneal macrophages) upon anti-CD4 treatment suggest that systemic ILl $\beta$ may have limited importance in acute AIA.

Unexpectedly, anti-CD4 treatment significantly increased the ILI $\beta$ release by LPS/IFN $\gamma$ stimulated peritoneal macrophages ex vivo. This finding suggests the existence of regulatory peritoneal macrophage subpopulations predominantly expressing ILI $\beta$, as supported by the following observations: $(a)$ the enhanced IL1 $\beta$ secretion was not seen in any other compartment; $(b)$ the release of the macrophage product NO was diminished by clinically effective anti-CD4 treatment; and $(c)$ there was a significant negative correlation between joint swelling and ILl $\beta$ production by peritoneal macrophages. Indeed, the FcR positive monocyte subset shows higher expression of ILl $\beta$ than the FCR negative subset, ${ }^{27}$ a population specifically overrepresented in inflammatory conditions like sepsis. ${ }^{28}$

\section{A proinflammatory role for NO}

Anti-CD4 treatment decreased NO production by stimulated peritoneal macrophages in parallel with reduction of arthritis in AIA, suggesting a proinflammatory role for $\mathrm{NO}$ in the present system. Given that other studies in AIA have reported $\mathrm{NO}$ as an anti-inflammatory factor, ${ }^{29}$ the net effects of NO on inflammation may depend on the individual tissue and/or organ and cell type. Thus, therapeutic application of iNOS inhibitors should be viewed with particular care (reviewed by Kinne et $a l^{2}$ ).

\section{Possible dual role of TNF $\alpha$}

As in the case of ILI $\beta$, anti-CD4 treatment of murine AIA had divergent effects on systemic and local levels of TNF $\alpha$ (reduction in the serum and increase in the joint). 
Although TNF $\alpha$ is usually regarded as a proinflammatory cytokine, in this study the local levels were increased (about $25 \%$ ) by clinically effective anti-CD4 treatment and negatively correlated with joint swelling (fig 3 ). Indeed, evidence is growing that $\mathrm{TNF} \alpha$ can also have immunosuppressive effects in some models of autoimmune disease, including arthritis. ${ }^{30} 31$

In general, the expression of TNF $\alpha$ in the arthritic joint was relatively low in mouse AIA (about 20-fold lower than ILl $\beta$ in IgG treated AIA mice), which is similar to the equivalent AIA model in the rat (own unpublished observations). Although TNF $\alpha$ is a known inducer of proinflammatory cytokines like ILI $\beta,^{32}$ the anti-CD4 induced increase of local TNF $\alpha$ was not sufficient to counteract the anti-CD4 induced decrease of ILl $\beta$. Thus, ILI $\beta$ may have a more important role than TNF $\alpha$ in joint inflammation/destruction in arthritis. ${ }^{33}$ However, it must be considered that small amounts of TNF $\alpha$ may still be sufficient to promote synovitis. ${ }^{34} 35$

\section{Effects of anti-CD4 treatment on proteolytic activity} Because anti-CD4 treatment inhibited joint destruction in AIA, a possible influence on matrix degrading proteases was also investigated. Indeed, a reduced "total" MMP activity was seen already on day 3. However, the specific MMP target(s) of anti-CD4 treatment remains to be determined because gelatin zymography showed that neither the activity of gelatinase A (MMP-2) nor of gelatinase B (MMP-9) was affected in the acute phase of AIA, and because the activities of MMP-1, -3 , or -13 were not visible in casein zymography.

In addition to the decreased MMP activity, the activity of NE was almost completely blocked. Earlier studies have shown that NE is a major protease of PMNs involved in proteoglycan damage. ${ }^{36}$ Moreover, NE can activate latent MMP present in the cartilage (for example, MMP-2, -3, and -9), leading to the generation of VDIPEN neoepitopes in the cartilage of animals with immune complex mediated arthritis. ${ }^{37}$ Consequently, the specific NE inhibitor MeOSucAla-Ala-Pro-Val-CMK completely inhibited proteoglycan depletion in this model. ${ }^{37}$

ILl $\beta$ is a known inducer of pro-MMPs, ${ }^{38}$ which are reduced by anti-CD4 treatment. Also, pro-MMPs require processing by other proteases (such as NE) to become active enzymes. Therefore, reduced local levels of ILI $\beta$ (resulting in a lower local level of pro-MMPs) and the decreased NE activity in arthritic joints may synergistically contribute to reduced joint destruction after anti-CD4 treatment.

\section{Indirect influence of anti-CD4 treatment on the functions of $\mathrm{CD4}^{-}$macrophages/PMNs}

It is presently unclear how anti-CD4 treatment affects the functions of macrophages or PMNs in AIA. The lack of CD4 expression on these cell populations in the mouse excludes the possibility of direct effects. An indirect influence of $\mathrm{CD} 4^{+}$ $\mathrm{T}$ cells on macrophages/PMNs seems probable, because the production of IFN $\gamma$ is significantly reduced in the spleen and/ or lymph node cells after anti-CD4 treatment, ${ }^{39}$ potentially resulting in counteraction of systemic macrophage activation. Because anti-CD4 treatment did not suppress $\mathrm{T}$ cell cytokines in the inflamed joint, ${ }^{39}$ a local influence of $\mathrm{T}$ cell deactivation on macrophage/PMN functions appears unlikely.

Anti-CD4 treatment decreased the NE activity in joint extracts without influencing the density of infiltrating PMNs. This excludes depletion of PMNs or an influence on their trafficking to the inflamed joint-for example by suppressing the production of chemotactic, T cell derived IL17. ${ }^{40}$ Rather, decreased NE activity may be mediated by an influence of anti-CD4 mAbs on contact dependent stimulation of PMNs by $\mathrm{T}$ cells. ${ }^{41}$ Such changes in PMN stimulation may reciprocally influence $\mathrm{T}$ cell activation-for example, through the suppression of elastin receptors on activated Th or $\mathrm{T}$ memory cells ${ }^{42}$ or through the potential of PMNs to act as accessory cells for $\mathrm{T}$ cell activation. ${ }^{43}$ Because the down regulation of $\mathrm{T}$ cell activation by anti-CD4 treatment is restricted to systemic sites, ${ }^{39}$ this treatment may result in a failure to stimulate the proinflammatory response of monocytes/PMNs before infiltrating the arthritic synovium.

\section{ACKNOWLEDGEMENTS}

Heidemarie Börner, Uta Griechen, Cornelia Hüttich, Waltraud Kröber, and Renate Stöckigt are gratefully acknowledged for excellent technical assistance, and Dr Ernesta Palombo-Kinne for critical revision of the manuscript.

This work was supported by the Bundesministerium für Bildung und Forschung (grants FKZ 01ZZ9602 and FKZ $01 Z Z 0105$ to RB and RWK) and the Deutsche Forschungsgemeinschaft (grants Br 1372/5 to RB and Ki 439/6-1 and Ki 439/7-1 to RWK).

\section{Authors' affiliations}

K Nissler, M Hückel, J Simon, R Bräuer, Institute of Pathology, Friedrich Schiller University, Jena, Germany

D Pohlers, R W Kinne, Experimental Rheumatology Unit, Interdisciplinary Centre of Clinical Research, Friedrich Schiller University, Jena, Germany

Present address of K Nissler: HELIOS Klinik Borna, Rudolf-Virchow-Str 2, D-04552 Borna, Germany

K Nissler and D Pohlers contributed equally to this work.

\section{REFERENCES}

1 Fox DA. The role of T cells in the immunopathogenesis of rheumatoid arthritis: new perspectives. Arthritis Rheum 1997;40:598-609.

2 Kinne RW, Bräuer R, Stuhlmüller B, Palombo-Kinne E, Burmester GR. Macrophages in rheumatoid arthritis. Arthritis Res 2000;2:189-202.

3 Pillinger MH, Abramson SB. The neutrophil in rheumatoid arthritis. Rheum Dis Clin North Am 1995;21:691-714.

4 Goronzy JJ, Weyand CM. Interplay of T-lymphocytes and HLA-DR molecules in rheumatoid arthritis. Curr Opin Rheumatol 1993;5:169-77.

5 Schulze-Koops H, Lipsky PE. Anti-CD4 monoclonal antibody therapy in human autoimmune diseases. Curr Dir Autoimmun 2000;2:24-49.

6 Mason U, Aldrich J, Breedveld F, Davis CB, Elliott M, Jackson M, et al. CD4 coating, but not CD4 depletion, is a predictor of efficacy with primatized monoclonal anti-CD4 treatment of active rheumatoid arthritis. J Rheumatol 2002;29:220-9.

7 Chu CQ, Londei $M$. Induction of Th2 cytokines and control of collagen-induced arthritis by nondepleting anti-CD4 Abs. J Immunol 1996;157:2685-9.

8 Pohlers D, Schmidt-Weber CB, Franch A, Kuhlmann J, Bräuer R, Emmrich F, et al. Differential clinical efficacy of anti-CD4 monoclonal antibodies in rat adjuvant arthritis is paralleled by differential influence on NF-kappaB binding activity and TNF-alpha secretion of T cells. Arthritis Res 2002;4:184-9.

9 Brackertz D, Mitchell GF, Mackay IR. Antigen-induced arthritis in mice. I. Induction of arthritis in various strains of mice. Arthritis Rheum 1977;20:841-50.

10 Yoshino S, Yoshino J. Suppression of chronic antigen-induced arthritis in rats by a monoclonal antibody against the T cell receptor alpha beta. Cell Immunol 1992;144:382-91.

11 Bräuer R, Kette H, Henzgen S, Thoss K. Influence of cyclosporin A on cytokine levels in synovial fluid and serum of rats with antigen-induced arthritis. Agents Actions 1994;41:96-8.

12 Petrow PK, Thoss K, Katenkamp D, Bräuer R. Adoptive transfer of susceptibility to antigen-induced arthritis into severe combined immunodeficient (SCID) mice: role of CD4+ and CD8+T cells. Immunol Invest 1996;25:341-53.

13 Simon J, Surber R, Kleinstäuber G, Petrow PK, Henzgen S, Kinne RW, et al. Systemic macrophage activation in locally-induced experimental arthritis. J Autoimmun 2001;17:127-36.

14 Bresnihan B. Pathogenesis of joint damage in rheumatoid arthritis. J Rheumatol 1999;26:717-19.

15 Horneff G, Sack U, Kalden JR, Emmrich F, Burmester GR. Reduction of monocyte-macrophage activation markers upon anti-CD4 treatment. Decreased levels of IL-1, IL-6, neopterin and soluble CD14 in patients with rheumatoid arthritis. Clin Exp Immunol 1993;91:207-13.

16 Gutman GA. Rat immunoglobulin allotypes. In: Weir DM, ed. Handbook of experimental immunology. Genetics and molecular immunology. Oxford: Blackwell Scientific, 1986:98.1-10.

17 Yui S, Sasaki T, Yamazaki M. Augmentation and suppression of TNF release from macrophages by inflammatory polymorphonuclear leukocyłes. Microbiol Immunol 1993;37:801-8.

18 Mentzel K, Bräuer R. Matrix metalloproteinases, IL-6, and nitric oxide in rat antigen-induced arthritis. Clin Exp Rheumatol 1998;16:269-76. 
19 Knight CG, Willenbrock F, Murphy G. A novel coumarin-labelled peptide for sensitive continuous assays of the matrix metalloproteinases. FEBS Lett 1992;296:263-6.

20 Pelegri $C$, Kühnlein $P$, Buchner $E$, Schmidt $C B$, Franch A, Castell $M$, et al. Depletion of gamma/delta $T$ cells does not prevent or ameliorate, but rather aggravates, rat adjuvant arthritis. Arthritis Rheum 1996;39:204-15.

21 Williams RO, Marinova-Mutafchieva L, Feldmann M, Maini RN. Evaluation of TNF-alpha and IL-1 blockade in collagen-induced arthritis and comparison with combined anti-TNF-alpha/anti-CD4 therapy. J Immunol 2000;165:7240-5.

22 Buchner E. Behandlung der antigen-induzierten Arthritis der Ratte mit AntiMakrophagenprinzipien und monoklonalen Anti-CD4 Antikörpern [dissertation]. Erlangen-Nürnberg: Friedrich-Alexander-Universität, 1996.

23 van de Loo FA, Kuiper S, van Enckevort FH, Arntz OJ, van den Berg WB. Interleukin-6 reduces cartilage destruction during experimental arthritis. A study in interleukin-6-deficient mice. Am J Pathol 1997;151:177-91.

24 de Hooge AS, van de Loo FA, Arntz OJ, van den Berg WB. Involvement of IL6, apart from its role in immunity, in mediating a chronic response during experimental arthritis. Am J Pathol 2000;157:2081-91.

25 Ohshima S, Saeki Y, Mima T, Sasai M, Nishioka K, Nomura S, et al. Interleukin 6 plays a key role in the development of antigen-induced arthritis. Proc Natl Acad Sci USA 1998;95:8222-6.

26 Brink I, Thiele B, Burmester GR, Trebeliahr G, Emmrich F, Hiepe F. Effects of anti-CD4 antibodies on the release of IL-6 and TNF-alpha in whole blood samples from patients with systemic lupus erythematosus. Lupus 1999;8:723-30

27 Pryjma J, Mytar B, Loppnow H, Ernst M, Zembala M, Flad HD. FcR+ and FcRmonocytes differentially secrete monokines during pokeweed mitogen-induced T-cell-monocyte interactions. Immunology 1992;75:355-60.

28 Schinkel C, Sendtner R, Zimmer S, Faist E. Functional analysis of monocyte subsets in surgical sepsis. J Trauma 1998;44:743-8.

29 Veihelmann A, Landes J, Hofbaver A, Dorger M, Refior HJ, Messmer K, et al. Exacerbation of antigen-induced arthritis in inducible nitric oxide synthasedeficient mice. Arthritis Rheum 2001;44:1420-7.

30 Kassiotis G, Kollias G. TNF and receptors in organ-specific autoimmune disease: multi-layered functioning mirrored in animal models. J Clin Invest 2001;107:1507-8.

31 Campbell IK, O'Donnell K, Lawlor KE, Wicks IP. Severe inflammatory arthritis and lymphadenopathy in the absence of TNF. J Clin Invest 2001; 107:1519-27.

32 Feldmann M, Brennan FM, Maini RN. Role of cytokines in rheumatoid arthritis. Annu Rev Immunol 1996;14:397-440.
33 Joosten LA, Helsen MM, Saxne T, van de Loo FA, Heinegard D, van den Berg WB. IL-1 alpha beta blockade prevents cartilage and bone destruction in murine type II collagen-induced arthritis, whereas TNF-alpha blockade only ameliorates joint inflammation. J Immunol 1999;163:5049-55.

34 Alsalameh S, Winter K, Al-Ward R, Wendler J, Kalden JR, Kinne RW. Distribution of TNF-alpha, TNF-R55 and TNF-R75 in the rheumatoid synovial membrane: TNF receptors are localized preferentially in the lining layer; TNFalpha is distributed mainly in the vicinity of TNF receptors in the deeper layers. Scand J Immunol 1999;49:278-85.

35 Alsalameh S, Amin RJ, Kunisch E, Jasin HE, Kinne RW. Preferential induction of prodestructive matrix metalloproteinase-1 and proinflammatory interleukin 6 and prostaglandin E2 in rheumatoid arthritis synovial fibroblasts via tumor necrosis factor receptor-55. J Rheumatol 2003;30:1680-90.

36 Moore AR, Iwamura H, Larbre JP, Scott DL, Willoughby DA. Cartilage degradation by polymorphonuclear leucocytes: in vitro assessment of the pathogenic mechanisms. Ann Rheum Dis 1993;52:27-31.

37 van Meurs J, van Lent P, Holthuysen A, Lambrou D, Bayne E, Singer I, et al. Active matrix metalloproteinases are present in cartilage during immune complex-mediated arthritis: a pivotal role for stromelysin-1 in cartilage destruction. J Immunol 1999; 163:5633-9.

38 Borghaei RC, Rawlings PL Jr, Mochan E. Interleukin-4 suppression of interleukin-1-induced transcription of collagenase (MMP-1) and stromelysin 1 (MMP-3) in human synovial fibroblasts. Arthritis Rheum 1998:41:1398-406.

39 Pohlers D, Nissler K, Frey O, Simon J, Petrow PK, Kinne RW, et al. Anti-CD4 monoclonal antibody treatment in acute and early chronic antigen-induced arthritis: influence on T helper cell activation. Clin Exp Immunol 2004; 135:409-15.

40 Laan M, Cui ZH, Hoshino H, Lotvall J, Sjostrand M, Gruenert DC, et al Neutrophil recruitment by human IL-17 via C-X-C chemokine release in the airways. J Immunol 1999; 162:2347-52.

41 Li JM, Isler P, Dayer JM, Burger D. Contact-dependent stimulation of monocytic cells and neutrophils by stimulated human T-cell clones. Immunology 1995;84:571-6.

42 Peterszegi G, Texier S, Robert L. Human helper and memory lymphocytes exhibit an inducible elastin-laminin receptor. Int Arch Allergy Immunol 1997:114:218-23.

43 Radsak M, Iking-Konert C, Stegmaier S, Andrassy K, Hansch GM. Polymorphonuclear neutrophils as accessory cells for T-cell activation: major histocompatibility complex class II restricted antigen-dependent induction of WeirT-cell proliferation. Immunology 2000;101:521-30. 